\title{
Effect of salinity, humic acid, biozote and vermicompost on soil physicochemical properties and olive plants species
}

\author{
Muhammad Arshad Ullah ${ }^{1 *}$, Syeda Sana Aamir ${ }^{1}$, Hussnain Haider ${ }^{2}$, Bilal Adil ${ }^{2}$, Imdad Ali \\ Mahmood ${ }^{1}$, Badar-uz-Zaman' ${ }^{1}$ and Syed Ishtiaq Hyder ${ }^{1}$ \\ ${ }^{1}$ National Agricultural Research Centre, Park Road, Islamabad-45500, Pakistan. \\ 2Institute of Soil Sciences, University of Arid Agriculture, Rawalpindi, Punjab, Pakistan. \\ ${ }^{*}$ Corresponding author. Email: arshadullah1965@gmail.com
}

Copyright @ 2018 Ullah et al. This article remains permanently open access under the terms of the Creative Commons Attribution License 4.0, which permits unrestricted use, distribution, and reproduction in any medium, provided the original work is properly cited.

Received 2nd February 2018; Accepted 9th April 2018

\begin{abstract}
The study was carried out at National Agricultural Research Centre (NARC) Islamabad during August, 2017 to October, 2017 to evaluate the impact of salinity plus humic acid, Biozote and Vermicompost on 3 olive varieties (Nocellera, Frontoio and Carolea) on physicochemical properties of soil and plant ionic concentration used in plastic nursery bags of three months olive sprouted cuttings in tunnel under saline conditions. The completely randomized design was applied with three replications. Olive soil salinity was developed artificially with the mixture of different salts at 2.0 $\mathrm{dSm}^{-1}$. Biozote, humic acid, and Vermicompost were applied in the artificially developed soil salinity filled in polythene bags planted three months olive cuttings. Treatments were; humic acid solid mixed with soil at the time of planting, humic acid liquid to the soil at the time of planting, humic acid sprayed to cuttings (after every 10 days), dip cuttings in humic acid at the time of planting. Addition of vermizote in soil at the time of planting, addition of Biozote in soil at the time of planting and dip cutting in biozote at the time of planting. Results showed that salinity negatively affected the uptake of nutrient elements. Physiochemical properties of soil showed significant variations among different treatments when interacted with varieties at $P<0.05$. This study pointed out the tolerance and sensitivity levels against salinity in three olive varieties at $2.0 \mathrm{dSm}^{-1}$. Nocellera olive variety is the most tolerant variety in terms of Na uptake as compared to the others. Whereas the Frontoio olive cultivar is the most susceptible olive variety against salinity stresses. As $\mathrm{K}$ uptake is concerned, Nocellera is the variety of maximum uptake and Carloea olive variety with the minimum. The results depicted that Nocellera olive variety proved to be the most salinity tolerant variety.
\end{abstract}

Key Words: Biozote Carolea, Frontoio and Nocellera, olive varieties, humic acid, ionic concentration, soil properties, vermicompost.

\section{INTRODUCTION}

Humic acids are technically not a fertilizer, even though in some ways people do think it. Humic acids are an effectual mediator to use as a hormone to synthetic or organic fertilizers. Humic acids are an important soil component that can improve nutrient availability and impact on other important chemical, biological, and physical properties of soils. In many examples, regular humic acids use will lessen the need for fertilization due to the soil and plant ability to make better use of it. In some ways, nutrition can be eliminated entirely if sufficient organic material is present and the soil can become self-sustaining through microbial processes and humus production (Hauser and Horie, 2010). Defline et al. (2005) investigated the effect of foliar application of $\mathrm{N}$ and humic acids on the growth and yield of corn. Moreover, other researchers specified that the foliar application of humic acids caused a transitional 
production of plant dry mass with respect to the unfertilized control (Guo et al., 2001, 2004 and Halfter et al., 2000).

As mentioned above, one way the plant growth can be improved is through the structural improvement of sandy clay soil allowing for a better root growth development (Ren et al., 2005 and Ishitani et al., 2000). The plant growth is also improved by the ability of the plant to uptake and receives more nutrients. Humic acids are especially beneficial in freeing up nutrients in the soil so that they are made available to the plant as needed. For instance, if an aluminum molecule is bound to one of phosphorus, humic acids detach them making the phosphorus available for the plant. Humic acids are also important because of their ability to chelate micronutrients, thus increasing their bioavailability (Sunarpi et al., 2005). According to the analysed results, the application of $20 \mathrm{mM} \mathrm{NaCl}$ increased the dry weight, N, P, K, Ca, Mg, Fe, Cu, and Mn contents of the plants, but the amounts decreased with the application of $60 \mathrm{mM} \mathrm{NaCl}$. Particularly, the effect of $\mathrm{NaCl}$ application at a dose of $60 \mathrm{mM}$ had a negatively significant effect on the dry weight and mineral elements uptake of corn (Pardo et al., 2006).

The soil applications of humus had a significant effect on the uptake of $\mathrm{N}$ in corn (Laila et al., 2017). When compared with the control treatment, the dry weight and mineral nutrients uptake of corn was found higher at both application doses of humus. The highest dry weight and nutrients uptake were obtained with $2 \mathrm{~g}$ humus $/ \mathrm{kg}$ treatment. The dry weight and nutrients uptake were negatively affected by the application of $4 \mathrm{~g}$ humus $/ \mathrm{kg}$ (Davenport et al., 2007; Mäser et al., 2002a). Angelova et al. (2013) reported that compost and vermicompost treatments had significant effect on soil physical and chemical properties like electrical conductivity (EC), $\mathrm{pH}$, organic matter, macro, and micronutrients content. Horie et al. (2001) compared with unamended soil and soil treated with organic amendments showed apparent increases of organic matter, total $\mathrm{N}, \mathrm{pH}, \mathrm{EC}$ and available macro elements ( $\mathrm{P}, \mathrm{K}, \mathrm{Ca}$ and $\mathrm{Mg}$ ).

Foliar applications of humic acid had a significant effect on the dry weight and mineral elements uptake in corn (Sunarpi et al., 2005; Uozumi et al., 2000). Addition of organic matter amendments, such as compost, fertilizers, and wastes, is a common practice for immobilization of heavy metals and soil amelioration of contaminated soils (Xue et al., 2011). Some researchers showed that amendment of contaminated soils with organic matter reduced the bioavailability of heavy metals (Khan et al., 2000; Liu et al., 2000; Qiu et al., 2002). Tavakkoli et al. (2010) reported that salinity caused by high concentrations of $\mathrm{NaCl}$ can reduce growth by the accumulation of high concentrations of both $\mathrm{Na}^{+}$and $\mathrm{Cl}^{-}$simultaneously, but the effects of the two ions may differ. High $\mathrm{Cl}^{-}$concentration reduces the photosynthetic capacity and quantum yield due to chlorophyll degradation which may result from a structural impact of high $\mathrm{Cl}^{-}$concentration on PSII (Davenport et al., 2007; Møller et al., 2009). High Na+ interferes with $\mathrm{K}^{+}$and $\mathrm{Ca}_{2}+$ nutrition and disturbs efficient stomata regulation which results in a depression of photosynthesis and growth. These results suggest that the importance of $\mathrm{Cl}^{-}$toxicity as a cause of reductions in growth and yield under salinity stress may have been underestimated. Salinity is a major constraint to crop production in Australia (Rengasamy, 2002; Mäser et al., $2002 b$ ) but there has been some recent debate about the importance of soil $\mathrm{Cl}$ and by implication plant $\mathrm{Cl}^{-}$uptake, as the principal cause of damage and yield loss at field level (Dang et al., 2010). Based on analysis of a number of field trials of wheat and chickpea crops, Dang et al. (2008) concluded that the $\mathrm{Cl}^{-}$concentration in the soil was more important in reducing growth and yield than $\mathrm{Na}$. Plants must cope with both osmotic and ionic stress under high salinity conditions. Osmotic stress reduces water uptake and cell expansion and delays lateral bud development (Munns and Tester, 2008; Berthomieu et al., 2003).

High cytosolic $\mathrm{K}+/ \mathrm{Na}+$ ratios in the shoot are critical for salt tolerance in glycophytes, which can only tolerate relatively low salt concentrations (Blumwald, 2000, Yamaguchi and Blumwald, 2005). When a $\mathrm{Na}+$ ion enters the plant root, it can be selectively transported through three independent biological membranes: the plasma membrane in epidermal cells, the vacuolar membrane in root and shoot cells, and the plasma membrane in xylem parenchyma cells (Horie et al., 2012). Accumulated cytosolic $\mathrm{Na}+$ can be removed by efflux systems such as $\mathrm{Na}+/ \mathrm{H}+$ antiporters, which transport $\mathrm{Na}+$ across the plasma membrane (Blumwald, 2000), as well as the SaltOverly Sensitive (SOS) pathway (Park et al., 2016).

Humin, which is composed of humic and fulvic acids (commonly known as humic substances [HS]), is a complex supramolecular association of abiotically transformed biomolecules that are released into soils after cell lysis (Orsi, 2014). These substances can improve soil properties such as aggregation, aeration, permeability, water holding capacity, micronutrient transport, and availability. Furthermore, the direct uptake of HS into plant tissues results in diverse biochemical outcomes (Arancon et al., 2006; Nardi et al., 2002; Selim et al., 2009; Tan, 2003). Humic acid (HA) improves plant development by regulating metabolic and signaling pathways by acting directly on certain targets in diverse physiological processes (Quaggiotti et al., 2004; Trevisan et al., 2010). HA treatment enhances the mobilization of toxic heavy metals, especially from abandoned mine tailings, indicating that HA could be utilized as a possible remedy to reduce further soil contamination (Wang and Mulligan, 2009). Moreover, HA has protective effects against high saline stress by inhibiting $\mathrm{Na}+$ uptake in barley (Marketa et al., 2016), and it reduces yield losses in maize under salt stress (Masciandaro et al., 2002). However, this study was conducted to investigate the effect of biozote, vermicompost and humic acid on soil physiochemical properties as well as plant ionic concentration under saline conditions. 
Table 1. Impact of salinity plus humic acid, biozote and vermicompost on physicochemical properties of soil.

\begin{tabular}{|c|c|c|c|c|c|c|c|c|c|c|c|c|c|c|c|c|}
\hline \multirow{2}{*}{ Treatment } & \multicolumn{4}{|c|}{ Soil $\mathrm{ECe}\left(\mathrm{dSm}^{-1}\right)$} & \multicolumn{4}{|c|}{ Soil $\mathrm{Na}\left(\mathrm{meql}^{-1}\right)$} & \multicolumn{4}{|c|}{ Soil $K\left(\right.$ meql $\left.^{-1}\right)$} & \multicolumn{4}{|c|}{ Soil $\mathrm{Ca}+\mathrm{Mg}\left(\mathrm{meql}^{-1}\right)$} \\
\hline & V1 & V2 & V3 & Mean & V1 & V2 & V3 & Mean & V1 & V2 & V3 & Mean & V1 & V2 & V3 & Mean \\
\hline T1 & $0.98^{\mathrm{ab}}$ & $0.93^{b c}$ & $0.92^{b c}$ & $0.94^{\mathrm{BC}}$ & $6.3^{a}$ & $6.5^{a}$ & $5.2^{a}$ & $6.2^{A}$ & $13.6^{a}$ & $13.4^{a}$ & $12.3^{a}$ & $13.1^{\mathrm{A}}$. & $1.9^{a b}$ & $1.7^{\mathrm{b}}$ & $1.6^{b}$ & $1.7^{\mathrm{B}}$ \\
\hline T2 & $0.92^{b c}$ & $0.95^{b c}$ & $0.91^{b c}$ & $0.92^{\mathrm{BC}}$ & $5.7^{\mathrm{a}}$ & $6.6^{\mathrm{a}}$ & $5.2^{\mathrm{a}}$ & $5.6^{\mathrm{A}}$ & $12.3^{a}$ & $14.6^{\mathrm{a}}$ & $11.2^{\mathrm{ab}}$ & $12.7^{\mathrm{A}}$ & $1.7^{\mathrm{b}}$ & $1.5^{\mathrm{b}}$ & $1.7^{b}$ & $1.6^{\mathrm{B}}$ \\
\hline T3 & $0.93^{b c}$ & $0.93^{b c}$ & $0.94^{b c}$ & $0.93^{\mathrm{BC}}$ & $6.0^{\mathrm{a}}$ & $5.9^{a}$ & $5.6^{a}$ & $6.1^{\mathrm{A}}$ & $15.6^{a}$ & $15.1^{\mathrm{a}}$ & $14.7^{\mathrm{a}}$ & $15.1^{\mathrm{A}}$ & $1.6^{\mathrm{b}}$ & $1.4^{\mathrm{b}}$ & $1.8^{\mathrm{ab}}$ & $1.6^{\mathrm{B}}$ \\
\hline T4 & $0.94^{b c}$ & $0.9^{3 b c}$ & $0.90^{\mathrm{bc}}$ & $0.92^{\mathrm{BC}}$ & $6.9^{a}$ & $6.3^{a}$ & $4.9^{b}$ & $5.9^{A}$ & $17.0^{\mathrm{a}}$ & $17.1^{\mathrm{a}}$ & $13.8^{a}$ & $16.0^{\mathrm{A}}$ & $1.4^{\mathrm{b}}$ & $1.5^{\mathrm{b}}$ & $1.9 \mathrm{ab}$ & $2.3^{A}$ \\
\hline T5 & $1.43^{\mathrm{ab}}$ & $1.40^{\mathrm{b}}$ & $1.46^{\mathrm{ab}}$ & $1.43^{\mathrm{AB}}$ & $4.8^{a b}$ & $6.7^{a}$ & $5.2^{\mathrm{a}}$ & $5.2^{\mathrm{A}}$ & $09.7^{b}$ & $11.3^{b}$ & $09.4^{b}$ & $10.1^{\mathrm{B}}$ & $2.6^{\mathrm{a}}$ & $2.4^{\mathrm{a}}$ & $2.0^{\mathrm{a}}$ & $2.3^{\mathrm{A}}$ \\
\hline T6 & $1.89^{a}$ & $1.97^{a}$ & $1.99^{a}$ & $1.95^{\mathrm{A}}$ & $4.0^{\mathrm{b}}$ & $4.0^{\mathrm{b}}$ & $4.5^{b}$ & $4.5^{\mathrm{B}}$ & $09.3^{b}$ & $08.9^{b}$ & $08.9^{b}$ & $09.0^{\mathrm{B}}$ & $1.3^{b}$ & $1.8^{\mathrm{ab}}$ & $2.1^{a}$ & $1.7^{\mathrm{B}}$ \\
\hline T7 & $1.82^{\mathrm{a}}$ & $2.00^{a}$ & $1.94^{a}$ & $1.92^{\mathrm{A}}$ & $3.9^{b}$ & $4.3^{b}$ & $4.6^{b}$ & $4.6^{\mathrm{B}}$ & $09.2^{b}$ & $08.0^{b}$ & $08.8^{b}$ & $08.7^{\mathrm{B}}$ & $1.5^{\mathrm{b}}$ & $1.6^{\mathrm{b}}$ & $1.9 \mathrm{ab}$ & $1.7^{\mathrm{B}}$ \\
\hline LSD & \multicolumn{4}{|c|}{0.46} & \multicolumn{4}{|c|}{1.8} & \multicolumn{4}{|c|}{5.7} & \multicolumn{4}{|c|}{0.7} \\
\hline
\end{tabular}

Means with different letters are significantly different at $5 \%$ level of probability. Before Plantation: Soil ECe $\left(\mathrm{dSm}^{-1}\right)=0.194$, Soil Na $\left(\mathrm{meql}^{-1}\right)=1.0, \mathrm{Soil} \mathrm{K}\left(\mathrm{meql}^{-1}\right)=2.4$, Soil Ca+Mg $\left(\mathrm{meql}^{-1}\right.$ $\left.{ }^{1}\right)=1.8 . V_{1}=$ Nocellera,$V_{2}=$ Frontoio, $V_{3}=$ Carloea, $T_{1}=$ Humic acid solid to mix with soil at the time of planting, $T_{2}=$ Humic acid liquid to soil at the time of planting, $T_{3}=$ Humic acid spray to cuttings (after every 10 days, $T_{4}=$ Dip cuttings in humic acid at the time of planting, $T 5=$ Addition of Vermizote in soil at the time of planting, $T_{6}=$ Addition of Biozote in soil at the time of planting, $T_{7}=$ Dip cutting in Biozote at the time of planting.

\section{MATERIAL AND METHODS}

The study was carried out at National Agricultural Research Centre (NARC), Islamabad between August to October, 2017 to probe the impact of salinity plus humic acid, Biozote and Vermicompost on 3 olive varieties (Nocellera, Frontoio and Carolea) on physicochemical properties of soil and plant ionic concentration used in plastic nursery bags of three months olive sprouted cuttings in tunnel under saline conditions. A Completely Randomized Design was applied with three replications. Olive Soil salinity was developed artificially with the mixture of different salts at 2.0 $\mathrm{dSm}^{-1}$. Biozote, humic acid, and Vermicompost were applied in the artificially developed soil salinity filled in polythene bags planted three months olive cuttings. Treatments were; $T_{1}=$ Humic acid solid to mix with soil at the time of planting, $\mathrm{T}_{2}=$ Humic acid liquid to soil at the time of planting, $\mathrm{T}_{3}=$ Humic acid spray to cuttings (after every 10 days, $\mathrm{T}_{4}=\mathrm{Dip}$ cuttings in humic acid at the time of planting, T5 = Addition of Vermizote in soil at the time of planting,
$\mathrm{T}_{6}=$ Addition of Biozote in soil at the time of planting, $T_{7}=$ Dip cutting in Biozote at the time of planting. Soil and leaf samples were analyzed for various physicochemical properties using standard methods (Ryan et al., 2001; Sparks et al, 1996). Soil EC, $\mathrm{Na}, \mathrm{K}$ and $\mathrm{Ca}+\mathrm{Mg}$ were determined. Leaf $\mathrm{Na}$ and $\mathrm{K}$ were also determined. The data collected was analysed and the means were compared by LSD at $5 \%$ level of probability (Montgomery, 2001).

\section{RESULTS AND DISCUSSION}

Three olive varieties were evaluated for salinity tolerance. Physiochemical properties of soil showed significant variations among different treatments when interacted with varieties at $P<0.05$ (Table 1). Soil EC was significantly higher $(2.00$ $\mathrm{dSm}^{-1}$ ) at $\mathrm{T}_{7}$ in $\mathrm{V}_{2}$ (Frontoio), followed by $1.99 \mathrm{dSm}^{-}$ 1 and $1.97 \mathrm{dSm}^{-1}$ at $\mathrm{T}_{6}$ in $\mathrm{V}_{3}$ and $\mathrm{V}_{2}$, respectively. Maximum mean of $E C$ was obtained with $\mathrm{T}_{6}$ followed by $T_{7}$ and the maximum mean of soil EC was achieved by $\mathrm{V}_{2}$ among other two olive varieties.
Soil $\mathrm{Na}\left(\mathrm{meql}^{-1}\right)$ was maximum $\left(6.9 \mathrm{meql}^{-1}\right)$ at $\mathrm{T}_{4}$ in $V_{1}$ (Nocellera), followed by 6.7 meq $^{-1}$ and 6.6 meql $^{-1}$ in $V_{2}$ at $T_{5}$ and $T_{2}$ respectively. Maximum mean soil $\mathrm{Na}$ was developed by $\mathrm{T}_{1}$ and maximum mean achieved in $V_{3}$ (Carloea). Salinization is one of the most serious types of land degradation as well as and a major obstacle to the optimal utilization of land resources (Liang et al., 2005). Humin influences plant growth both directly and indirectly by functioning as a major source of organic compounds in soil (Sangeetha et al., 2006).

Soil $\mathrm{K}$ was significantly higher $\left(17.1 \mathrm{meql}^{-1}\right)$ at $\mathrm{T}_{4}$ in $V_{2}$ followed by 17.0 meql $^{-1}$ at $T_{4}$ in $V_{1}$. The maximum mean soil $\mathrm{K}$ was obtained by $\mathrm{T}_{4}$ in $\mathrm{V}_{1}$.

Maximum soil $\mathrm{Ca}+\mathrm{Mg}\left(2.6 \mathrm{meql}^{-1}\right)$ was achieved at $T_{5}$ by $V_{1}$ followed by 2.4 meql $^{-1}$ and 2.0 meql $^{-1}$ at $T_{5}$ by $V_{2}$ and $V_{3}$, respectively. The maximum means were achieved by $\mathrm{T}_{4}\left(2.3 \mathrm{meql}^{-1}\right)$ and $\mathrm{T}_{5}\left(1.9 \mathrm{meql}^{-}\right.$ 1) by $V_{3}$.

Statistical analysis showed that $V_{1}$ was more tolerant against treatments $T_{4}, T_{5}, T_{6}$ and $T_{7}$ with the difference of $0.2 \mathrm{meql}^{-1}$ of $\mathrm{Na}$ before and after 
Table 2. Leaf analysis before the conductance of the experiment and after the harvest of the experiment.

\begin{tabular}{|c|c|c|c|c|c|c|c|c|c|c|c|c|}
\hline \multirow{3}{*}{ Treatment } & \multicolumn{6}{|c|}{ Leaf $\mathrm{Na}\left(\mathrm{meql}^{-1}\right)$} & \multicolumn{6}{|c|}{ Leaf $\mathrm{K}\left(\mathrm{meql}^{-1}\right)$} \\
\hline & \multicolumn{2}{|c|}{$V_{1}$} & \multicolumn{2}{|c|}{$V_{2}$} & \multicolumn{2}{|c|}{$V_{3}$} & \multicolumn{2}{|c|}{$V_{1}$} & \multicolumn{2}{|c|}{$\mathrm{V}_{2}$} & \multicolumn{2}{|c|}{$V_{3}$} \\
\hline & Before & After & Before & After & Before & After & Before & After & Before & After & Before & After \\
\hline T1 & $2.2^{b}$ & $2.5^{a}$ & $2.5^{a}$ & $2.5^{\mathrm{a}}$ & $2.1^{\mathrm{b}}$ & $2.0^{\mathrm{b}}$ & 10.6 & 10.8 & 9.3 & 9.6 & 9.2 & 9.3 \\
\hline T2 & $2.2^{\mathrm{b}}$ & $2.2^{\mathrm{b}}$ & $2.2^{\mathrm{b}}$ & $2.6^{\mathrm{a}}$ & $2.1^{\mathrm{b}}$ & $2.3^{b}$ & 10.3 & 10.7 & 9.2 & 9.7 & 9.0 & 9.3 \\
\hline T3 & $2.1^{\mathrm{b}}$ & $2.3^{b}$ & $2.3^{b}$ & $2.7^{a}$ & $2.2^{\mathrm{b}}$ & $2.1^{b}$ & 10.4 & 10.4 & 9.9 & 9.9 & 9.9 & 9.9 \\
\hline $\mathrm{T} 4$ & $2.4^{\mathrm{a}}$ & $2.2^{\mathrm{b}}$ & $2.2^{\mathrm{b}}$ & $2.4^{\mathrm{a}}$ & $2.1^{\mathrm{b}}$ & $2.2^{\mathrm{b}}$ & 09.9 & 10.4 & 9.1 & 9.1 & 9.1 & 9.0 \\
\hline T5 & $2.1^{\mathrm{b}}$ & $1.9^{\mathrm{c}}$ & $1.9^{\mathrm{c}}$ & $2.1^{\mathrm{b}}$ & $2.0^{\mathrm{b}}$ & $2.6^{a}$ & 09.8 & 10.8 & 9.6 & 9.6 & 9.6 & 9.2 \\
\hline T6 & $2.2^{\mathrm{b}}$ & $2.0^{\mathrm{b}}$ & $2.0^{\mathrm{b}}$ & $2.1^{\mathrm{b}}$ & $1.9^{b}$ & $2.2^{\mathrm{b}}$ & 10.2 & 10.4 & 9.0 & 9.7 & 9.0 & 9.5 \\
\hline T7 & $2.3^{\mathrm{b}}$ & $2.1^{\mathrm{b}}$ & $2.1^{b}$ & $2.3^{b}$ & $2.0^{\mathrm{b}}$ & $2.1^{\mathrm{b}}$ & 10.1 & 10.5 & 9.5 & 9.8 & 9.3 & 9.6 \\
\hline LSD & & & 0. & & & & & & $\mathrm{NS}$ & & & \\
\hline
\end{tabular}

Means with different letters are significantly different at $5 \%$ level of probability. $\mathrm{V}_{1}=$ Nocellera, $\mathrm{V}_{2}=\mathrm{Frontoio}, \mathrm{V}_{3}=\mathrm{Carloea}$, $\mathrm{T}_{1}=$ Humic acid solid to mix with soil at the time of planting, $\mathrm{T}_{2}=$ Humic acid liquid to soil at the time of planting, $\mathrm{T}_{3}=\mathrm{Humic}$ acid spray to cuttings (after every 10 days, $\mathrm{T}_{4}=$ Dip cuttings in humic acid at the time of planting, T5 $=$ Addition of Vermizote in soil at the time of planting, $\mathrm{T}_{6}=$ Addition of Biozote in soil at the time of planting, $\mathrm{T}_{7}=\mathrm{Dip}$ cutting in Biozote at the time of planting.

the applications of soil treatments (Table 2). Analysis of $\mathrm{V}_{2}$ showed that the Na uptake was nill in $\mathrm{T}_{1}$ and the Na uptake difference was +0.4 meql $^{-1}$ in $T_{2}$ and $T_{3}$ which shows its sensitiveness. Na uptake by $\mathrm{V}_{3}$ showed its tolerance of 0.1 meql $^{-1}$ with $T_{1}$ and $T_{3}$ but at $T_{5}$ the difference of +0.6 meql $^{-1}$ showed the sensitivity of $\mathrm{V}_{3}$ at $\mathrm{T}_{5}$ (Table 2).

Statistical analysis of $\mathrm{K}$ uptake showed that $\mathrm{V}_{1}$ attained $1.00 \mathrm{meq}^{-1} \mathrm{~K}$ uptakes by $\mathrm{T}_{5}$ followed by the difference of +0.5 meql $^{-1}$ with $\mathrm{T}_{4} . \mathrm{V}_{2}$ showed maximum $\left(+0.7\right.$ meql $\left.^{-1}\right) \mathrm{K}$ uptake by $T_{5}$ followed by $T_{2}\left(+0.5\right.$ meql $\left.^{-1}\right)$. $V_{3}$ achieved highest $\mathrm{K}$ uptake of +0.5 meql $^{-1}$ by $\mathrm{T}_{6}$ followed by $\mathrm{T}_{2}$ and $\mathrm{T}_{3}\left(+0.3 \mathrm{meql}^{-1}\right) \mathrm{K}$ uptake. Humic Acid has protective effects against high saline stress by inhibiting $\mathrm{Na}$ + uptake in barley (Marketa et al., 2016), and it reduces yield losses in maize under salt stress (Masciandaro et al., 2002).

The statistical analysis confirmed the tolerance and sensitivity levels of three olive varieties. $V_{1}$ is the most tolerant variety in terms of $\mathrm{Na}$ uptake as compared to the others. Whereas $V_{2}$ is the most susceptible variety of olive against salinity stress. As $\mathrm{K}$ uptake is concerned, $\mathrm{V}_{1}$ is the variety with maximum uptake and $V_{3}$ with minimum. The results depicted to be the most Salinity tolerant variety. Olive is basically considered as moderately saline tolerant but the plant response to salinity depends on genotypes (Weissbein et al., 2008). Salinity stress ability of olive includes its anatomical, physiological and morphological alteration of leaf level (Aparicio et al., 2014). Whereas $\mathrm{NaCl}$ tolerance is related to salt prevention at root level, which inhibits the accumulation of $\mathrm{Na}^{+}$in leaves as well as the ability of olive plant to sustain/retain crucial potassium $\left(\mathrm{K}^{+}\right) /$sodium $\left(\mathrm{Na}^{+}\right)$ratio (Chartzoulakis et al., 2002).

\section{CONCLUSION}

This study concluded that the tolerance and sensitivity levels against salinity among three olive varieties.
Nocellera olive variety is the most tolerant variety in terms of Na uptake as compared to the others. Whereas Frontoio olive cultivar is the most susceptible variety of olive against salinity stresses. As for as, $\mathrm{K}$ uptake is concerned, Nocellera is the variety with maximum uptake and Carloea olive variety with minimum. The results depicted that Nocellera olive variety proved to be the most salinity tolerant variety.

\section{CONFLICT OF INTEREST}

The authors declare that they have no conflict of interest.

\section{REFRENCES}

Angelova, V. R., Akova, V. I., Artinova, N. S., \& Ivanov, K. I. (2013). The effect of organic amendments on soil chemical characteristics. Bulg. J. Agric. Sci, 19(5), 958-971.

Aparicio, A., Urrestarazu, M. \& Cordovilla, M. D. P. (2014). Comparative Physiological Analysis of Salinity Effects in Six Olive Genotypes. Hortscience, 49 (7), 901-904.

Arancon, N. Q. C., Edwards, A., Lee, S., \& Byrne, R. (2006). Effects of humic acids from vermin composts on plant growth. Euro. J. Soil Biol. 42, 65-69.

Berthomieu, P., Conejero, G., Nublat, A., Brackenbury, W.J., Lambert, C., Uozumi, N., Oiki, S., Yamada, K., Cellier, F., Gosti, F., 2003. Functional analysis of AtHKT1 in Arabidopsis shows that $\mathrm{Na}+$ recirculation by the phloem is crucial for salt tolerance. EMBO J., 22, 2004-2014.

Blumwald, E. (2000). Sodium transport and salt tolerance in plants. Curr. Opin. Cell Biol.,12, 431-434.

Chartzoulakis, K., Loupassaki, M., Bertaki, M., \& Androulakis. I. (2002). Effects of $\mathrm{NaCl}$ salinity on growth, ion content and $\mathrm{CO} 2$ assimilation rate of six olive cultivars. Sci. Hort., 96:235-247.

Dang, Y. P., Dalal, R. C., Mayer, D. G. (2008). High subsoil chloride concentrations reduce soil water extraction and crop yield on Vertisols in north-eastern Australia. Australian Journal 
of Agricultural Research, 59, 321-330.

Dang, Y.P., Dalal, R.C., Buck, S.R., Harms, B., Kelly, R., Hochman, Z., Schwenke, G. D., Biggs, A. J. W., Ferguson, N. J., Norrish, S., \& Routley, R. (2010). Diagnosis, extent, impacts and management of subsoil constraints in the northern grains cropping region of Australia. Soil Research, 48(2), 105119.

Davenport, R. J., Munoz-Mayor, A., Jha, D., Essah, P. A., Rus, A., Tester, M. (2007). The Na+ transporter AtHKT1;1 controls retrieval of $\mathrm{Na}+$ from the xylem in Arabidopsis. Plant Cell Environ., 30, 497-507.

Defline, S., Tognetti, R., Desiderio, E., Alvino, A. (2005). Effect of foliar application of $\mathrm{N}$ and humic acids on growth and yield of durum wheat. Agronomy for Sustainable Development, 25: 183-191.

Guo, Y., Halfter, U., Ishitani, M., \& Zhu, J. K. (2001). Molecular characterization of functional domains in the protein kinase SOS2that is required for plant salt tolerance. Plant Cell, 13, 1383-1400.

Guo, Y., Qiu, Q. S., Quintero, F. J., Pardo, J. M., Ohta, M., Zhang, C., Schumaker, K. S., \& Zhu, J. K. (2004). Transgenic evaluation ofactivated mutant alleles of $\mathrm{SOS}_{2}$ reveals a critical requirement for its kinase activity and $\mathrm{C}$-terminal regulatory domain for salt tolerance in Arabidopsis thaliana. Plant Cell, 16, 435-449.

Halfter, U., Ishitani M., \& Zhu, J. K. (2000). The Arabidopsis SOS2 protein kinase physically interacts with and is activated by thecalcium-binding protein SOS3. Proc. Natl. Acad. Sci., 97, 3735-3740.

Hauser, F., \& Horie, T. (2010). A conserved primary salt tolerance mechanism mediated by HKT transporters: a mechanism for sodium exclusion and maintenance of high $\mathrm{K}+/ \mathrm{Na}+$ ratio in leaves during salinity stress. Plant Cell Environ., 33, 552-565.

Horie, T., Karahara, I., \& Katsuhara, M. (2012). Salinity tolerance mechanisms in glycophytes: An overview with the central focus on rice plants. Rice, 5(1), 11.

Horie, T., Yoshida, K., Nakayama, H., Yamada, K., Oiki, S., \& Shinmyo, A. (2001). Two types of HKT transporters with differentproperties of $\mathrm{Na}+$ and $\mathrm{K}+$ transport in Oryza sativa. Plant J., 27, 129-138.

Ishitani, M., Liu, J., Halfter, U., Kim, C. S., Shi, W., \& Zhu, J. K. (2000). SOS3 function in plant salt tolerance requires $\mathrm{N}$ myristoylation and calcium binding. Plant Cell, 12, 1667-1678.

Khan, A. G., Kuek, C., Chandhry, T. M., Khoo, C. S. \& Hayes, W. J. (2000). Role of plants, mycorrhizae and phytochelatorsin heavy metal contaminated land remediation. Chemosphere, 41, 197-207.

Laila, K, Hee, J. P., Dae-Jin, Y., Jong-Rok, J., Min, G. K., JoonYung, C., \& Woe-Yeon, K. (2017). Humic acid confers highaffinity $\mathrm{k}+$ transporter 1 -mediated salinity stress tolerance in Arabidopsis. Mol. Cells, 40(12), 966-975.

Liang, Y., Si, J., Nikolic, M., Peng, Y., \& Chen, W. (2005). Organic manure stimulates biological activity and barley growth in soil subject to secondary salinization. Soil Biol. Biochem, 37(6), 1185-1195

Liu, J., Ishitani, M., Halfter, U., Kim, C. S., \& Zhu, J. K. (2000). The Arabidopsis thaliana SOS2 gene encodes a protein kinase that is required for salt tolerance. Proceedings of the National Academy of Sciences, 97, 3730-3734.

Marketa, J., Borivoj, K., Jozef, K., Petr, B., \& Josef, S. (2016). Humic acid protects barley against salinity. Acta. Physiol. Plant. 38, 161.

Masciandaro, G., Ceccanti, B., Ronchi, V., Benedicto, S., \&
Howard, L. (2002). Humic substances to reduce salt effect on plant germination and growth. Comm. Soil Sci. Plant Anal., 33, 365-378.

Mäser, P., Eckelman, B., Vaidyanathan, R., Horie, T., Fairbairn, D. J., Kubo, M., Yamagami, M., Yamaguchi, K., Nishimura, M. Uozumi, N. (2002a). Altered shoot/root $\mathrm{Na}$ + distribution and bifurcating salt sensitivity in Arabidopsis by genetic disruption of the $\mathrm{Na}$ + transporter AtHKT1. FEBS letters, 531(2), 157-161.

Mäser, P., Hosoo, Y., Goshima, S., Horie, T., Eckelman, B. Yamada, K., Yoshida, K., Bakker, E. P., Shinmyo, A., Oiki, S. \& Schroeder, J. I. (2002b). Glycine residues in potassium channel-like selectivity filters determine potassium selectivity in four-loop-per-subunit HKT transporters from plants. Proceedings of the National Academy of Sciences, 99(9), 6428-6433.

Møller, I. S., Gilliham, M., Jha, D., Mayo, G. M., Roy, S, J., Coates, J. C., Haseloff, J., \& Tester, M. 2009. Shoot Na+ exclusion and increased salinity tolerance engineered by cell type-specific alteration of $\mathrm{Na}+$ transport in Arabidopsis. Plant Cell, 21, 2163-2178.

Montgomery, D. C. (2001). Design and Analysis of Experiments. 5th ed., Wiley, New York.

Munns, R., \& Tester, M. (2008). Mechanisms of salinity tolerance. Annu. Rev. Plant Biol., 59, 651-681.

Nardi, S., Pizzeghello, D., Muscolo, A., \& Vianello, A. (2002). Physiological effects of humic substances on higher plant. Soil Biol. Biochem., 34, 1527-1536.

Orsi, M. 2014. Molecular dynamics simulation of humicsubstances. Chem. Biol. Technol. Agr., 1,10.

Pardo, J. M., Cubero, B., Leidi, E. O., \& Quintero, F. J. (2006). Alkali cation exchangers: roles in cellular homeostasis and stress tolerance. J. Exp. Bot., 57, 1181-1199.

Park, H. J., Kim, W. Y., Yun, D. J. (2016). A new insight of salt stress signaling in plant. Mol. Cells, 39(6), 447-459.

Qiu, Q. S., Guo, Y., Dietrich, M. A., Schumaker, K. S., \& Zhu, J. K. (2002). Regulation of SOS1, a plasma membrane $\mathrm{Na}+\mathrm{H}_{+}$ exchanger in Arabidopsis thaliana, by SOS2 and SOS3. Proceedings of the National Academy of Sciences, 99, 84368441.

Quaggiotti, S., Ruperti, B., Pizzeghello, D., Francioso, O., Tugnoli, V., \& Nardi, S. (2004). Effect of low molecular size humic substances on the expression of genes involved in nitrate transport and reduction in maize (Zea mays L.). J. Exp. Bot., 55, 803-813.

Ren, Z. H., Gao, J. P., Li, L. G., Cai, X. L., Huang, W., Chao, D. Y., Zhu, M. Z., Wang, Z. Y., Luan, S., and Lin, H. X. (2005). A rice quantitative trait locus for salt tolerance encodes a sodium transporter. Nat. Genet., 37, 1141-1146.

Rengasamy, P. (2002). Transient salinity and subsoil constraints to dry land farming in Australian sodic soils: an overview. Australian Journal of Experimental Agriculture, 42, 351-361.

Ryan, J., Estefan, G., \& Rashid, A. (2001). Soil and Plant Analysis Laboratory Manual. International Center for Agricultural Research in the Dry Areas (ICARDA), Islamabad, Pakistan. 172p.

Sangeetha, M., Singaram, P., \& Devi, R. D. (2006, July). Effect of lignite humic acid and fertilizers on the yield of onion and nutrient availability. In Proceedings of 18th World Congress of Soil Science July (pp. 9-15).

Selim, E. M., Mosa, A. A., \& El-Ghamry, A. M. (2009). Evaluation of humic substances fertigation through surface and subsurface drip irrigation systems on potato grown under Egyptian sandy soil conditions. Agr. Water Manage., 96, 12181222 
Sparks, D. L., Carski, T. H., Fendorf, S. E., Toner, C. V. (1996). Kinetic methods and measurements. Pp. 1275-1307. In D.L. Sparks (ed.) Methods of soil analysis: Chemical methods. Soil Science Society of America, Madison, WI.

Sunarpi, H. T., Horie, T., Motoda, J., Kubo, M., Yang, H., Yoda, K., Horie, R., Chan, W. Y., Leung, H. Y., Hattori, K., Konomi, M., Osumi, M. (2005). Enhanced salt tolerance mediated by AtHKT1 transporter-induced $\mathrm{Na}+$ unloading from xylem vessels to xylem parenchyma cells. Plant J., 44, 928-938.

Tan, K. H. (2003). Humic matter in soil and the environment. Marcel Dekker, New York.

Tavakkoli, E., Pichu, R., \& McDonald, G. K. (2010). High concentrations of $\mathrm{Na}+$ and $\mathrm{Cl}-$ ions in soil solution havesimultaneous detrimental effects on growth of fababeanunder salinity stress. Journal of Experimental Botany, 61(15), 4449-4459.

Trevisan, S., Pizzeghello, D., Ruperti, B., Francioso, O., Sassi, A., Palme, K., Quaggiotti, S., \& Nardi, S. 2010. Humic substances induce lateral root formation and expression of the early auxin responsive IAA19 gene and DR5 synthetic element in Arabidopsis. Plant Biol., 12, 604-614.

Uozumi, N., Kim, E. J., Rubio, F., Yamaguchi, T., Muto, S., Tsuboi, A., Bakker, E. P., Nakamura, T., \& Schroeder, J. I. (2000). The Arabidopsis HKT1 gene homolog mediates inward $\mathrm{Na}+$ currents in Xenopus laevis oocytes and $\mathrm{Na}+$ uptake in Saccharomyces cerevisiae. Plant physiology, 122(4), 12491260.
Wang, S., \& Mulligan, C. N. (2009). Enhanced mobilization of arsenic and heavy metals from mine tailings by humic acid. Chemosphere, 74, 274-279.

Weissbein, S., Wiesman, Z., Ephrath, Y., \& Silberbush, M. (2008). Vegetative and reproductive response of olive cultivars to moderate saline water irrigation. Hort. Science, 43,320-327.

Xue, S., Yao, X., Luo, W., Jha, D., Tester, M., Horie, T., \& Schroeder, J. I. (2011). AtHKT1;1 mediatenernstian sodium channel transport properties in Arabidopsis root stelar cells. PLoS One, 6, e24725.

Yamaguchi, T., \& Blumwald E. (2005). Developing salt tolerant crop plants: Challenges and opportunities. Trends Plant Sci., 10, 615-620. 